\title{
EPUBの多国語対応に向けた取組と事例報告
}

\section{EPUB Activities for Enhanced Global Language Support}

\author{
秋元良仁 \\ Ryoji AKIMOTO
}

\author{
凸版印刷株式会社 \\ TOPPAN PRINTING CO., LTD. \\ 于112-8531 東京都文京区水道1-3-3 \\ E-mail: ryoji.akimoto@toppan.cp.jp
}

電子書籍のグローバルフォーマットとして期待されているEPUBの次期バージョン仕様改訂が進ん でいる. 次期バージョンでは, 電子書籍を表現する新しい試みとして, アノテーション・ナビゲーショ ン・メタデータ技術, ページネーションやレイアウトに関する技術, HTML5やCSS3等Webを中心とし た技術の導入はもとより, 縦書き, ルビ, 禁則処理, 文字セット拡張等の東アジア語圏特有の検討課 題についてもその実現に向け活発な議論がなされている.

本稿では, 特にEPUBの多国語化に向けて行われている取り組みを中心に, その標準化動向につ いていくつかの事例を交えて報告し, 今後の展望について言及する.

EPUB specification development as the global e-book format is progressing to the next version. EPUB specifications consist of web technologies such as annotation, navigation, metadata, pagination, layout, and HTML5/CSS3 etc. Experts discuss applying web technologies and solutions for CJKT issues in next version of EPUB. The CJKT issues consist of vertical writing, ruby, line breaking rule, and character set extension etc.

In this paper, we summarize the current status of EPUB standardization activities, focusing on CJKT discussions. And we also describe the future works of them.

キーワード：電子書籍, EPUB, 多国語化, CSS3, Web

Keyword: e-book, EPUB, Global language support, CSS3, Web 


\section{1 はじめに}

2010年は電子書籍元年と呼ばれるほど出版 業界における電子化に向けた動きが活発であ る[1]. 電子書籍端末と称される様々な読書用 デバイスの発売, 読者に書籍を届ける配信プラ ットフォームの研究開発, ビジネスプレイヤーに よる各種業界団体の設立等, 話題を挙げれば 枚挙に暇がない.このような状況において, 読 者がいつでもどこでも書籍にアクセスでき，それ を読むことができる環境の確立には電子書籍フ オーマットの標準化が必要不可欠である.

これまでにも各国の書籍特性を反映したフォ ーマット[2]やデバイス特性を考慮したフォーマ ット[3]等, 様々なフォーマットの策定が試みられ てきた.しかしながら, それらのフォーマットの多 くは仕様が非公開であるため, プロプライエタリ なソフトウェア環境でしか閲覧ができない場合 が多く, 多様な読書環境に対応しきれないとい う問題が内在していた。

このような問題に対し, 近年では米国を中心 に開発が進められているオープン規格の電子 書籍フォーマットEPUBに注目が集まっている [4]. EPUBはシンプルな内部構造を持ち,かつ 構成要素全般にWeb標準技術が用いられてい る. そのため, 多くのソフトウェアがEPUBに対応 しやすく,またソフトウェア間のデータ互換性も 得やすいといらメリットがある.

2010年に入り, EPUBは大幅な改訂作業の次 期を迎えている. 改訂内容として, HTML5や CSS3といった新しいWeb技術の導入検討はもと より, 縦書き・ルビ・禁則処理といった東アジア 語圈特有の書籍表現についてもその是非につ いて活発な議論が行われている.

本稿では特にEPUBの多国語化に向けて行 われている取り組みを中心に, その標準化活動 についていくつかの事例を交えて報告し, 今後 の展望について言及する.
2章ではEPUBのフォーマット策定の経緯につ いて述べる. 3章では現行のEPUB2.0の仕様に ついて概観する. また，関連する仕様について も説明を加える. 4章で現在行われている仕様 改訂の全体像を示し, 5章で特に多国語化対応 についていくつかの事例を交えつつ説明する. 最後に6章で今後を展望し, まとめと課題につ いて述べる.

\section{EPUB策定の経緯}

1990 年代後半, 米国 Microsoft 社は電子書 籍ビジネス参入にあたり, 電子書籍用フォー マット Open eBook 構想を提案した.この提案 に対し, 出版社や印刷会社, ソフトウェア・ハ ードウェアメーカー等約 40 社が賛同し, 1998 年 10 月に Open eBook Initiative が発足した.

翌 1999 年 9 月には米国国立標準技術局 （NIST）の支援のもと，EPUB の前身となる OEBPS1.0 ( the Open eBook Publishing Structure 1.0)が策定された. 仕様は XML べ 一スで開発され，オープンであったことから， 特定の端末ベンダに依存しない電子書籍コン テンツ制作が可能となった[5].

その後, Open eBook Initiative は 2002 年 2 月にフォーラム標準団体 Open eBook Forum (OeB)として組織化された. 同年 XHTML1. 1, CSS2 が取り入れられた OEBPS1.2 が策定され る.しかしながら,これまで中心的な役割を担 ってきた Microsoft 社が仕様開発から事実上 撤退したため, OeB の活動は停帯期を迎え る.

2005 年に入り, OeB は the International Digital Publishing Forum (IDPF) [6] と組織名 称が変更され, Adobe 社が積極的に関与する ようになる. 2006 年 7 月には Adobe 社主導の もと, 電子書籍向けパッケージ OCF1.0 (Open Container Format 1.0)[7]が策定される. 


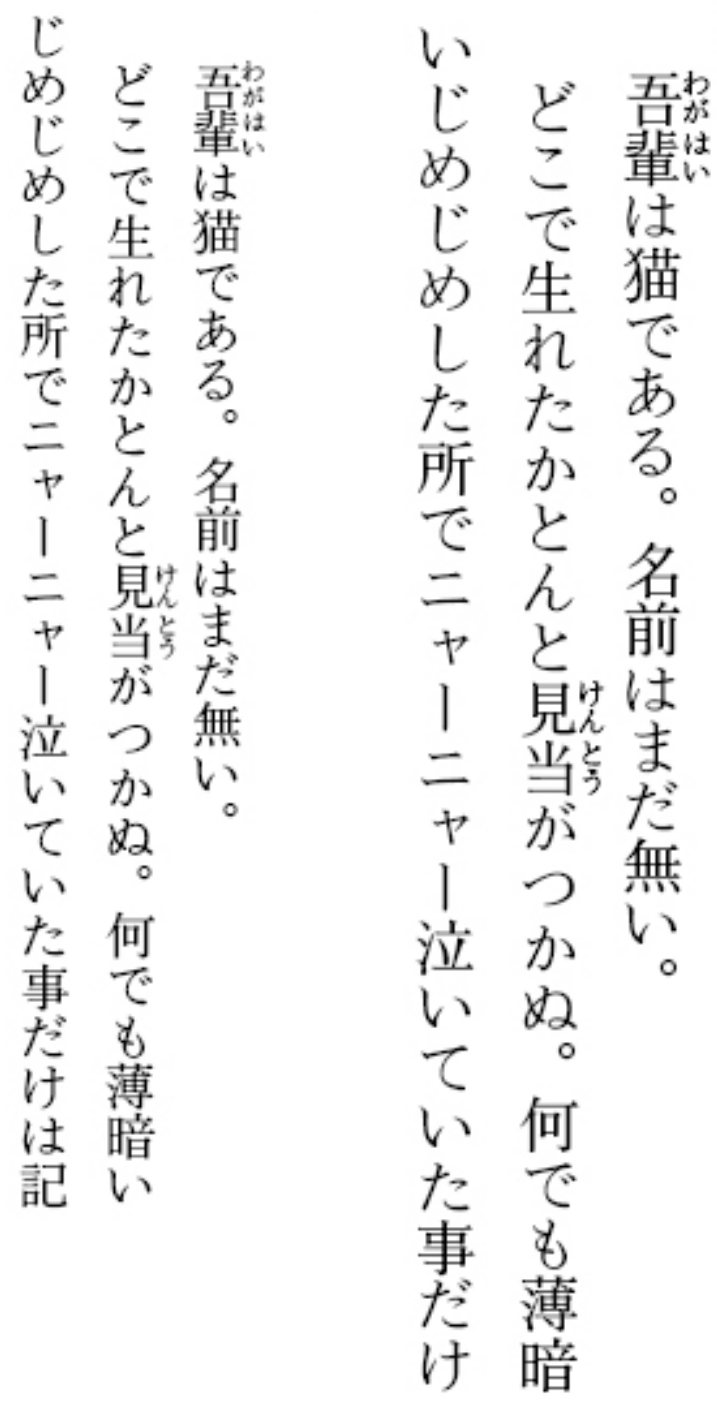

図 $1 \mathrm{Re}-\mathrm{flowable}$ なコンテンツ

OCF は OEBPS 形式で作られたコンテンツを ZIP アーカイブし，拡張子を「.epub」とすること が定められている.

その後, OEBPS はコンテンツの内容を記述 する OPS (Open Publication Structure) [8]とメ タデータを記述する OPF (Open Packaging Format)[9]に分割され，それらを OCF 形式で パッケージングするフォーマットとして 2007 年 9 月, EPUB2.0 が策定された.

\section{EPUBの特徵と構造}

\subsection{EPUBの特徵}

EPUB は次に示すいくつかの特徵を持つ.

1)フリーかつオープンなフォーマットである

プロプライエタリなソフトウェアやフォーマット で作成されたコンテンツはベンダのサポートが 消失した場合，以後利用できないコンテンツ になってしまう危険性を含んでいる. それに対 し, EPUB は仕様書が全て Web で公開されて おり, 誰でもその内容を確認し, 電子書籍コン テンツを作成することが可能である.

また, EPUB は仕様策定の過程についても メーリングリストや会議議事録等全てが公開さ れており,リアルタイムに更新状況を確認する ことも可能である.

2) Re-flowableなコンテンツである

「Re-flowable」とは，融通性があることを指 す.ここでは通常固定の原稿レイアウトに対し， レイアウトやそこに収まる文字・図版・写真等を 動的に再配置する処理を指寸 (図 1 参照). Re-flowable なコンテンツでは, コンテンツ制作 者, あるいはリーディングシステムが提供する レイアウトの指定值に基づいて都度版面を再 構成し, 様々なサイズのデバイスに最適なコン テンツ表示を行うことが可能となる. そのため， 読者が読みやすいと感じるレイアウトを持つコ ンテンツを提供できる反面, 制作者の意図が 完全に再現されたレイアウトでのコンテンツ提 供は困難となる.

3)メタデータを持つ

コンテンツは書籍に関するメタデータ (書誌 情報や書籍構成情報)を持つ. そのため, リー ディングシステムはメタデータに基づき目次ぺ ージを自動生成したり, 各ページの表示処理 を行ったりすることが可能となる.

また, コンテンツ配信元が提供する検索シ 


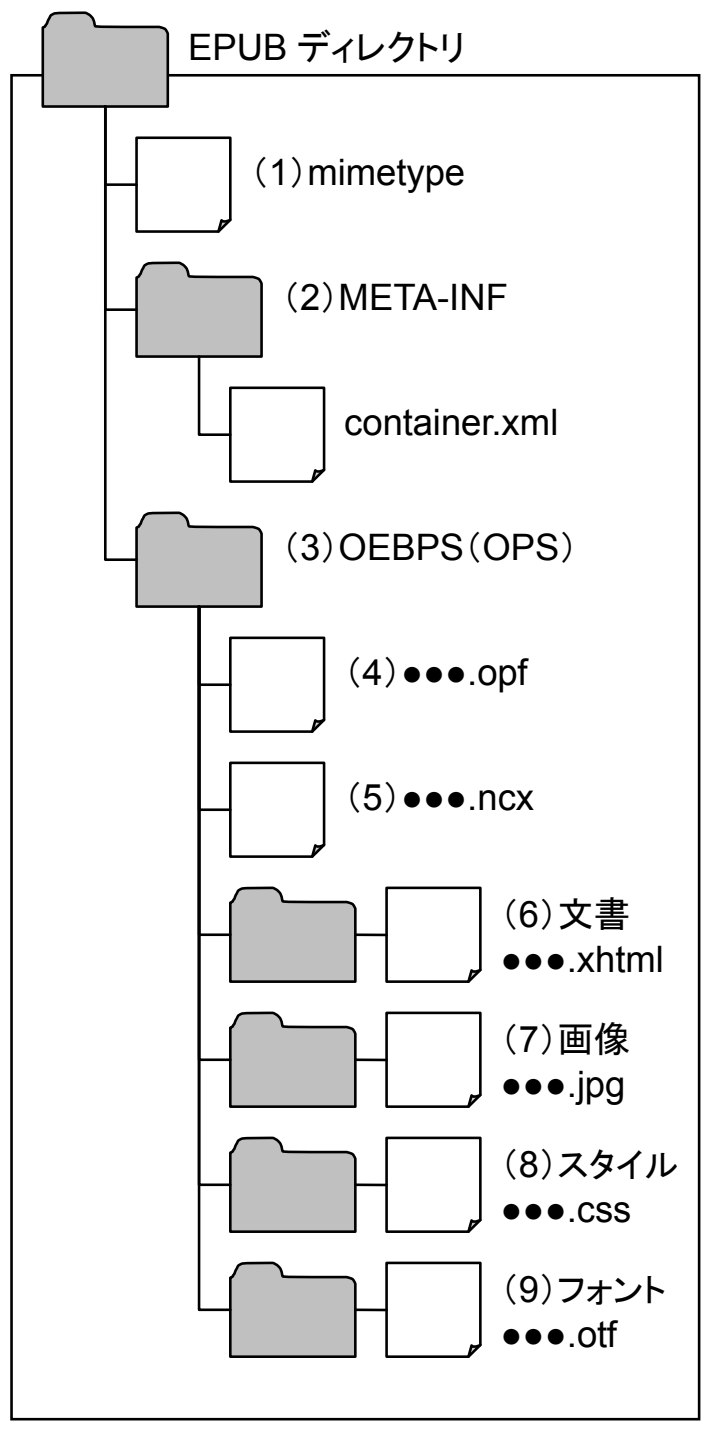

図 2 EPUB ファイルの基本構成

\section{\$ unzip $-x \star \star \star$.epub}

図 3 EPUB ファイルの解凍

ステムやベンダが提供するリーディングシステ ムにおいて,メタデータを用いた利便性の高 い検索サービスやコンテンツ管理方式をユー ザに提供することが可能となる.

4) 拡張性が高い(適合性が高い)

後述するが, EPUB はXHTML や CSS 等, Web で用いられる技術をベースとしたフォーマ ットである. そのため, Web 用の様々なボキャ
表 1 META-INF

\begin{tabular}{|c|c|}
\hline container.xml & $\begin{array}{l}\text { •必須/ファイル名予約 } \\
\text { •ディレクトリ直下に配置 } \\
\text { •OPFファイルのパスが記述 } \\
\text { 暗号化不可 }\end{array}$ \\
\hline manifest.xml & $\begin{array}{l}\text { •オプション/ファイル名予約 } \\
\text { OPF1.0 のスキーマ }\end{array}$ \\
\hline metadata.xml & $\begin{array}{l}\text { •オプション/ファイル名予約 } \\
\text { •妥当な XML (ただしスキー } \\
\text { マ規定はなし) }\end{array}$ \\
\hline signatures.xml & $\begin{array}{l}\text { •オプション } \\
\cdot X M L \text { 署名 } \\
\end{array}$ \\
\hline encryption.xml & $\begin{array}{l}\text { •オプション } \\
\text { •XML 暗号化 }\end{array}$ \\
\hline rights.xml & $\begin{array}{l}\text { •オプション } \\
\text { •整形式な XML }\end{array}$ \\
\hline
\end{tabular}

ブラリを用いることができ，書籍表現の拡張性 が高い。

また,リーディングシステムが拡張部分のボ キャブラリに対応していない場合，記述内容の 意味を損なわないように，コンテンツはその代 替情報(フォールバックアイテム)を提供しなけ ればならない。

\section{2 ファイル構成}

困 2 に EPUB2.0 のファイル構成を示す.な お，既存のEPUBファイルが存在する場合，例 えば図 3 のように unzip しファイル構成を確認 することができる.

以下, 図 2 の括弧番号に沿って各構成につ いて説明する.

(1) mimetype

MIMEタイプは application/epub+zip で固定 されている。また，ファイル名は ASCII で "mimetype"に固定されており,かつファイルは ZIPアーカイブしてはならない.

(2) META-INF

"META-INF"という名前のディレクトリをル 一卜直下に配置しなければならない.このディ レクトリには表 1 に示すメタ情報が格納される. 
(3) OEBPS (OPS)

"OEBPS"あるいは"OPS"という名前のディレ クトリをルート直下に配置しなければならない。 ディレクトリの中には, 書籍の構成要素やそれ らの相互関係を示す OPF ファイル (必須), 目 次データを示す NCX ファイル (必須), 文書 (必須), 画像 (オプション), スタイル情報 (オ プション)，フォント情報(オプション) 等が格納 される.

(4) OPF ファイル

文書・画像・スタイル, フォント情報といった 書籍を構成する部品の一覧や各部品の関係 性が記述される. OPF ドキュメントは主に以下 に示寸要素からなる.

- package

OPFドキュメントのルート要素. あらゆる他の 要素は package 要素の下にネストされる. また, 自身のユニークな ID 属性を持つ。

-metadata

メタデータ要素は書籍に関する情報を提供 する. 基本的に Dublin Core[10]に基づいてお り, 書籍のタイトルを示す title 要素, 書籍識別 子である identifier 要素, 書籍の言語を示す language 要素は必須となる.

-manifest

書籍を構成する各ドキュメント (文書, 画像, スタイル, フォント等)のリストを持つ. 各ファイ ルは item 要素でパスとメディアタイプが示され る.

- spine

manifest 要素で指定された各ドキュメントを 参照する itemref 要素を持つ. itemref 要素は ページの出現順に記述され, リーディングシス テムは itemref 要素の順番通りにページを読 み込み表示しなければならない。

- guide

spine 要素で指定された各ドキュメントへの
ファイルパス (type 属性)とその内容を示すメタ データ(title 属性)を持つ. type 属性の属性值 指定は必須であり, 表紙カバー, 目次, 索引, 用語集，本文リスト，挿絵リス卜等がある.

(5) NCX ファイル

書籍目次を示す。目次は NCX (Navigation Center Extended)と呼ばれ, コンテンツのアク セシビリティ向上を検討する国際共同開発機 関である DAISY コンソーシアム[11]によって標 準化された概念である。具体的には ANSI/NISO Z39.86-2005 Specifications for the Digital Talking Book[12]で定義される.

NCX では, 目次タイトル (docTitle 要素の子 要素 title 要素), 目次階層の深さ(meta 要素 の content 属性), ページ数 (meta 要素の name 属性が dtb:totalPageCount 属性值およ び dtb:maxPageNumber 属性值), 対応するフ アイルのパス(navPoint 要素の子要素 content 要素の src 属性), 入れ子構造による文書構 造の指定 (navPoint 要素)等を定義することが できる.

(6) 文書

EPUB 形式で記述される文書は， XHTML1.1ドキュメントタイプモジュール[13]が 推奨ボキャブラリとして定義される. そのため, 文書は XHTML1.1 の仕様に則り記述すること ができる.しかしながら，XHTML1.1 とは異な る意味や制約を持つ要素・属性も定義されて おり, そのため一般的には XHTML1.1 のサブ セットと呼ばれている.

また，仕様では推奨ボキャブラリとして DAISY コンソーシアムで策定された XML ベー スの DTBookドキュメントタイプも定義されてい る. そのため, DTBook 形式で記述される文書 も仕様に則った標準文書となる.

(7) 画像

画像はインラインの img 要素を用いて文書 
表 2 次期 EPUB 改訂に向けた課題（Charter）

\begin{tabular}{r|l}
\hline 1 & Rich media (ビデオ等)と Interactive なコンテンツ(クロスワードパズル等)をサポートすること \\
\hline 2 & 中国語, 日本語, 韓国語のような多国語をサポートすること \\
\hline 3 & 雑誌や新聞に見られる記事単位のサポートをすること \\
\hline 4 & ONIX, RDFa, PRISM 等のメタデータをサポートすること \\
\hline 5 & 動的なレイアウト・フォント変更を考慮したページレイアウトをサポートすること \\
\hline 6 & NCXを中心に強化されたナビゲーションをサポートすること \\
\hline 7 & 多くの Web ブラウザが広く採用しているWeb 標準との連携が不足していること \\
\hline 8 & ユーザ生成情報であるアノテーションのサポートが不足していること \\
\hline 9 & MathMLがサポートされていないため, 教科書・学術出版分野での相互運用性が制限されていること \\
\hline 10 & 用語集やクロスリファレンス等のネイテイブサポートがないこと \\
\hline 11 & 音声読み上げのメディアタイプサポート等, アクセシビリティサポートが不足していること \\
\hline 12 & 相互運用可能な状態で業界固有の拡張を行うための機構が不足していること \\
\hline 13 & 国際標準規格との関係が明確に示されていないこと \\
\hline
\end{tabular}

から参照される. 画像形式は OPS メディアタイ プを持つ形式が推奨されており，ラスタイメー ジとして GIF 形式, PNG 形式, JPEG (JFIF) 形 式, ベクタイメージとして SVG1.1 が規定されて いる.

(8) 画像

画像はインラインの img 要素を用いて文書 から参照される. 画像形式は OPS メディアタイ プを持つ形式が推奨されており, ラスタイメー ジとして GIF 形式, PNG 形式, JPEG (JFIF) 形 式, ベクタイメージとして SVG1.1 が規定されて いる.

(9) スタイル

スタイルは OPS スタイルシートで定義される。 OPS スタイルシートは CSS2 の構文に従ってお り，セミコロンで区切られた多重宣言による CSS 構築, スペース・タブ・キャリッジリターン等 の空白文字, link 要素や xml-stylesheet 処理 命令を介した外部リンクスタイルシート, セレク タの使用等をサポートする.

(10)フォント

コンテンツ制作者がテキストの体裁をある程 度制御できるよう, OPS では CSS2 の font-face 属性[14]をサポートしている.
情報の互換性を高めるため, フォント識別 子 font-family, font-style, font-variant, font-weight, font-size, src のみに限定した指 定を行う。また，OPFの manifest 要素において， 適切なメディアタイプの指定を行わなければ ならない。

\section{3 関連する仕様}

\subsection{1 他の仕様との関係}

EPUB を構成する OPS, OPF, OCF はそれ ぞれ他の仕様のサブセットおよびアプリケーシ ヨンが組み合わされている.

これら関連仕様も含めて EPUB を構成する ことでコンテンツの構築・編成・表示および変 換を容易にしている. 付録 1 に他の仕様との 関係について示す.

\subsubsection{XML Islands}

OPS は構成上関連する仕様をサブセットと して組み込む場合がある。 その際の組込処理 モデルを示すメカニズムに XML Islands があ る.

XML Islands では組み込む部分をフラグメン ト化し, フォールバック・リンク・切り替え用要 素・デフォルト要素等を指定することで OPS に 一貫した整合性を持たせている. 
表 4 サブグループとテーマ一覧

\begin{tabular}{|c|c|c|}
\hline 1 & Annotations & $\begin{array}{l}\text { コンテンツの注釈付与 (解説・脚注・正誤表・質疑応答メモ等)に関す } \\
\text { る拡張仕様の検討 (次期 EPUB 改訂と分離, 別規格として策定予定) }\end{array}$ \\
\hline 2 & EGLS & $\begin{array}{l}\text { グローバル言語サポートのための拡張仕様 } \\
\text { 主に東アジア語圈 (日本・中国・韓国・台湾)の言語・組版ルールに関 } \\
\text { する検討 }\end{array}$ \\
\hline 3 & Metadata & 書誌情報記述の検討 \\
\hline 4 & Navigation & 目次 (NCX) 仕様の改訂および DAISY 仕様の改訂 \\
\hline 5 & Text Content & HTML5 に向けた要件定義と仕様検討 \\
\hline 6 & Styling \& Layout & $\begin{array}{l}\text { ページネーションを中心としたテキストのスタイル付けとレイアウトに関 } \\
\text { する拡張仕様の検討 }\end{array}$ \\
\hline 7 & Rich Media and Interactivity & $\begin{array}{l}\text { 映像・音声等マルチメディア要素を取り入れた電子書籍/雑誌/教科 } \\
\text { 書の拡張仕様の検討 }\end{array}$ \\
\hline 8 & Advertisement & $\begin{array}{l}\text { コンテン゙ツの広告配信仕様の検討（Rich Media and Interactivity サブ } \\
\text { グループに吸収） }\end{array}$ \\
\hline
\end{tabular}

表 3 EPUB 改訂スケジュール

\begin{tabular}{l|l}
\hline $2010 / 06 / 15-16$ & 対面会議(キックオフ) \\
\hline $2010 / 06 / 24$ & $\begin{array}{l}\text { サブグループで要求項目の } \\
\text { 作成作業開始 }\end{array}$ \\
\hline $2010 / 07 / 23$ & $\begin{array}{l}\text { サブグループの要求項目をワ } \\
\text { ーキンググループヘ提出 }\end{array}$ \\
\hline $2010 / 08 / 27$ & $\begin{array}{l}\text { サブグループで実装案の検 } \\
\text { 討開始 }\end{array}$ \\
\hline $2010 / 08 / 27$ & $1^{\text {st } \text { Draft 作成開始 }}$ \\
\hline $2010 / 10 / 18-20$ & 対面会議 \\
\hline $2010 / 11 / 02$ & $1^{\text {st } \text { Draft 案レビュー }}$ \\
\hline $2010 / 11 / 12$ & 第 1 回 内部 Draft 共有 \\
\hline $2010 / 12 / 13$ & 第 2 回 内部 Draft 共有 \\
\hline $2011 / 01 / 29$ & $1^{\text {st } \text { Public Working Draft 公開 }}$ \\
\hline $2011 / 05 / 15$ & 次期 EPUB 仕様改訂 \\
\hline
\end{tabular}

\section{EPUBの仕様改訂とその内容}

\section{1 実現すべき目標とスケジュール}

2010 年 4 月, IDPF は次期 EPUB 仕様改訂 に向けて実現すべき目標 (Charter) [15]を検 討した. 現在, 13 の目標が草案として公開さ れている. 表 2 にその内容を示す.

目標を受け, IDPF では 2010 年 6 月から次 期 EPUB 検討ワーキンググループが発足し， 仕様の改訂作業を進めている. 表 3 に次期 EPUB 仕様改訂までの大まかなスケジュール
を示す(表は 2010 年 10 月現在のものであり， 都合により変更される可能性がある) [16].

ワーキンググループは主要テーマ別に 80 のサブグループに分かれている. 各サブグル ープはコーディネータと呼ばれるグループリー ダのもと, 次期 EPUB の仕様に盛り込むべき要 求項目およびその具体的な実装案を議論す る. 議論された内容は週 1 回の検討ワーキン ググループ電話会議で報告され, 2010 年 10 月の対面会議において実装案別に審議され る. 承認を得た案については Public Working Draft に反映される. Public Working Draft は 一定期間公開され, パブリックコメントやフィー ジビリティスタディ等を通じたフィードバックに 基づき加筆修正される.

以上のような内外からの十分な検証を経た 後で, 改定案は 2011 年 5 月 15 日に EPUB3.0 として正式にリリースされる予定である.

\section{2 サブグループの活動}

表 4 に検討ワーキンググループによって設 置されたサブグループとテーマの一覧を示 す.

各サブグループはそれぞれ平行して要求 項目設定や実装案検討を行うものの, 関連す 
表 5 EGLS 要求項目の概要

\begin{tabular}{|c|c|c|}
\hline No. & 項目 & 要求概要 \\
\hline $1(\mathrm{~A})$ & 綴じ方向 & OPS の綴じ方向を指定可能にする \\
\hline $2(\mathrm{~B})$ & 見開き & 扉や特定画像のために見開き指定を可能にする \\
\hline $3(\mathrm{~A})$ & 2 つの書字方向 & 「上下-右左」や「上下-左右」の書字方向を指定可能にする \\
\hline $4(\mathrm{~B})$ & デフォルト書字方向 & $\begin{array}{l}\text { OPS のデフォルト書字方向を指定可能にする. 書字方向は明示的に指定さ } \\
\text { れた場合を除き, OPS に適用される }\end{array}$ \\
\hline $5(\mathrm{~B})$ & 段方向 & デフォルト書字方向は段の配置を含む \\
\hline $6(\mathrm{~B})$ & $\begin{array}{l}\text { キャプション/表見出し } \\
\text { の書字方向 }\end{array}$ & $\begin{array}{l}\text { キャプション, 表見出し, 柱, ハンブルは縦書き書字方向であっても横書き書 } \\
\text { 字方向にする }\end{array}$ \\
\hline $7(\mathrm{~A})$ & $\begin{array}{l}\text { 各書字方向へのフォ } \\
\text { ールバック }\end{array}$ & 「上下-右左」から「左右-上下」へのフォールバックが必要 \\
\hline $8(\mathrm{C})$ & 最適なレイアウト提供 & デフォルト書字方向用に最適なコンテンツを準備する \\
\hline $9(\mathrm{C})$ & 非最適化 & どちらの書字方向が最適でないか指定できるようにする \\
\hline $10(\mathrm{~A})$ & 1つずつ回転 & 英数字が全角モノスペース文字なら和文字と同じ向きに 1 字 1 字配置 \\
\hline $11(\mathrm{~A})$ & 90 度回転 & 英数字がプロポーショナル文字なら, 時計回りに 90 度回転して配置 \\
\hline $12(\mathrm{~B})$ & 縦中横 & 縦中横指定を可能にする \\
\hline $13(\mathrm{C})$ & $\begin{array}{l}\text { 10〜12 のスタイル選 } \\
\text { 択 }\end{array}$ & $\begin{array}{l}\text { Reading System はプロバイダ設定やユーザ嗜好に応じて上記 } 3 \text { スタイルを選 } \\
\text { 択できるようにする }\end{array}$ \\
\hline $14(\mathrm{~B})$ & 行頭·行末禁則 (1) & Reading System は行頭行末禁則処理を実装する \\
\hline $15(\mathrm{C})$ & 行頭·行末禁則 (2) & プロバイダが行頭行末禁則文字種を指定できるようにする \\
\hline $16(\mathrm{~B})$ & 分割禁止文字(1) & Reading System は特定文字列に改行処理を導入しない \\
\hline $17(\mathrm{C})$ & 分割禁止文字(2) & プロバイダは分割禁止文字を指定できるようにする \\
\hline $18(\mathrm{C})$ & ぶら下がり(1) & Reading System はぶら下がり処理を実装する \\
\hline $19(\mathrm{C})$ & ぶら下がり(2) & プロバイダはぶら下がり文字を指定できるようにする \\
\hline $20(\mathrm{C})$ & 分離禁止文字 (1) & Reading System は特定文字列にスペースを導入しない \\
\hline $21(\mathrm{C})$ & 分離禁止文字(2) & プロバイダは分離禁止文字を指定できるようにする \\
\hline $22(\mathrm{~A})$ & モノルビ & $\begin{array}{l}\text { モノルビ指定を可能にする. フォールバック指定 (親文字のあとにルビ文字を } \\
\text { 入れる等)も可能にする }\end{array}$ \\
\hline $23(\mathrm{~A})$ & 熟語ルビ & $\begin{array}{l}\text { 熟語ルビ指定を可能にする. フォールバック指定 (親文字のあとにルビ文字 } \\
\text { を入れる等)も可能にする. 改行不可 }\end{array}$ \\
\hline $24(\mathrm{~A})$ & グループルビ & $\begin{array}{l}\text { グループルビ指定を可能にする. フォールバック指定 (親文字のあとにルビ } \\
\text { 文字を入れる等)も可能にする. 改行不可 }\end{array}$ \\
\hline $25(\mathrm{~B})$ & Bopomofo ルビ & CJK 文字に Bopomofo ルビ指定を可能にする \\
\hline $26(\mathrm{~A})$ & ルビ位置 (1) & 日本語:横書きの場合上, 縦書きの場合右に配置する \\
\hline $27(\mathrm{~B})$ & ルビ位置 $(2)$ & Bopomofo: 横書きの場合上か右, 縦書きの場合右に配置する \\
\hline $28(\mathrm{~B})$ & 両側ルビ & 親文字の両側にルビ指定を可能にする \\
\hline $29(\mathrm{~A})$ & $\begin{array}{l}\text { ユーザ嗜好やディス } \\
\text { プレイ設定によるルビ } \\
\text { 制御 }\end{array}$ & $\begin{array}{l}\text { Reading System はユーザ嗜好やディスプレイ設定でのルビ指定を許す. 従 } \\
\text { 来のルビ, ポップアップ, フォールバック, 読み上げ等 }\end{array}$ \\
\hline $30(\mathrm{~B})$ & 圈点 & 圈点指定を可能にする \\
\hline $31(\mathrm{~B})$ & Unicode/IEC 10646 & Unicode6.0 を指定可能にする \\
\hline $32(\mathrm{~A})$ & PUC の利用禁止 & PUC (Private Use Characters)の利用を禁止する \\
\hline $33(\mathrm{~A})$ & インライン画像 & $\begin{array}{l}\text { Reading System でサイズが変更されてもテキストになじむように画像を配置で } \\
\text { きるようにする }\end{array}$ \\
\hline $34(\mathrm{~A})$ & フォント埋め込み & SVG フォントや WOFF が埋め込めるようにする \\
\hline $35(\mathrm{~B})$ & メタデータの読み & メタデータに漢字・仮名文字の両方を指定可能にする \\
\hline $36(\mathrm{~B})$ & 言語継承 & 自然言語を指定したら他の OPF/OPS でも同じ指定が反映する \\
\hline $37(\mathrm{~A})$ & 正規化 & Unicode 正規化を適用することなしに EPUBドキュメントの生成を可能にする \\
\hline
\end{tabular}


縦書き書籍

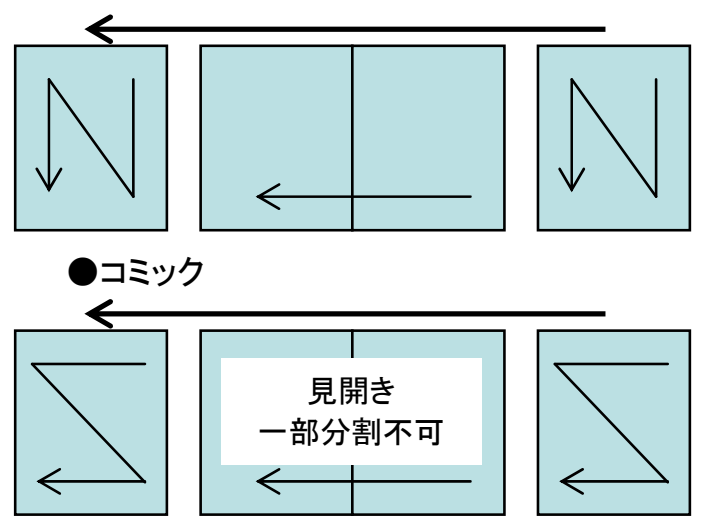

○横書き書籍

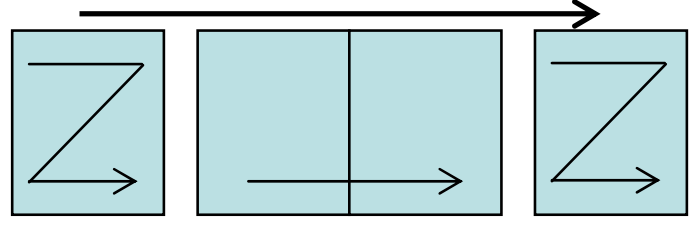

図 4 緅じ方向

る部分に関してはグループ間で連携して作業 が進められている。

また, 一部のサブグループは検討ワーキン ググループ内に留まらず, 他の標準仕様策定 団体とのリエゾンやタスクフォースの設置を模 索し, 仕様策定を推進している.

なお, 当初設置された 8 グループは議論を通 じて 10 月の時点で 6 グループに集約されてい る.

\section{5 多国語化の対応状況}

\subsection{EGLSサブグループ}

EGLS (Enhanced Global Language Support) サブグループ[17]は EPUB を多国語化する際 の言語・組版要求の取りまとめを行うグループ である。EGLS では次期 EPUB（以下 EPUB3.0)に取り入れられるべき要求項目を整 理し, 実装案を議論した上で検討ワーキング グループに改訂案の提案を行っている.

グループはコーディネータ(国際大学の村 田真氏)を中心にIRC (Internet Relay Chat)シ
ステムによるミーティング, 2 回におよぶ対面会 議(第 1 回札幌会議[18]:2010/08/03-04, 第 2 回台湾台北会議[19]:2010/10/05-06)を通 じて議論を重ねている.

会議には正式なメンバー(IDPF の会員であ り, 日本・韓国・台湾が中心) 以外に, Invited Expert としてW3C の仕様エディタや ISO の標 準化専門委員等も参加しており, 将来に渡っ て利用に耐えうる EPUB の多国語化対応につ いて, 様々な技術的観点で検討がなされた.

\section{2 要求項目の概要}

表 5 にEGLS において検討された要求項目 の概要を示す. 要求項目は「Page Progression Direction (No.1 2) 」, 「Vertical Writing (No.3 $\sim 9)\lrcorner\lceil$ Mixed Text $($ No.10 14)」, 「Line Breaking Rule (No.14 21)」, 「Ruby and Emphasis Dots (No.22 30)」, 「Characters or Glyphs (No.31 34)」「Others (No.35 37)」 の大項目に割り振られている. EGLS メンバー は各項目の優先度を数值化して投票し, 計数 結果を A から C のランキング[20]に割り振って いる(表では No.に括弧書きでランキングを示 している).

次項以降, 提案の各論について実装の事 例を踏まえながら説明する. なお，見出しの番 号 $(\mathrm{A} \sim \mathrm{J})$ は検討ワーキンググループに提出し た実装提案に基づいている[21].

\section{3 実装提案}

\section{Recommendation A}

書籍にはページの進行方向が含まれる.一 般的に, 横書きの書籍は左緅じ, 縦書きの書 籍や漫画は右緅じである(図 4 参照)。現行の EPUB ではこれら綴じの方向が制御できない. そのため, 例えば見開き固定でページ表示し たい場合, 左右のページが逆転してしまう場 合がある. そこで, OPF ファイル内で指定され る spine 要素に page-progression-direction 属 


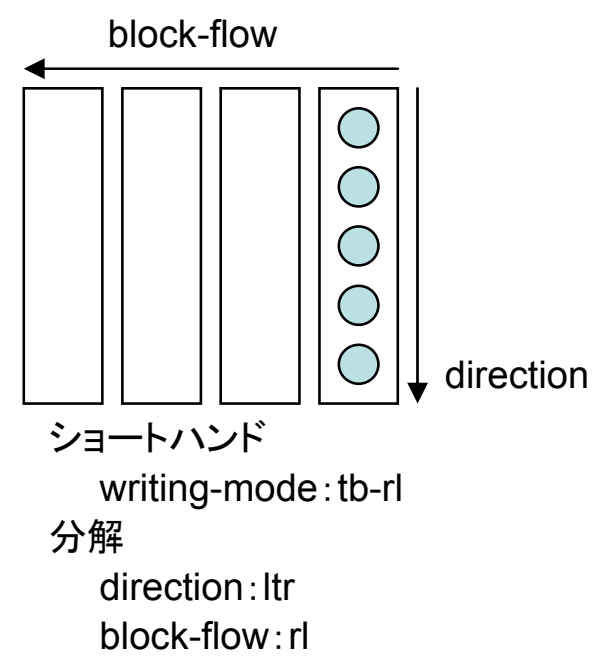

図 5 writing-mode

○水平方向スタイル指定

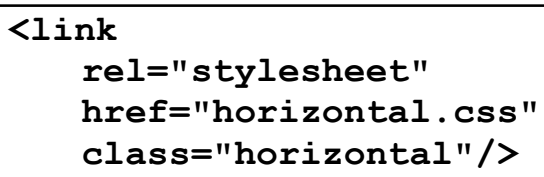

垂直方向スタイル指定

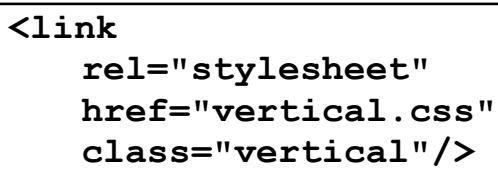

水平 ·垂直両方のスタイル指定

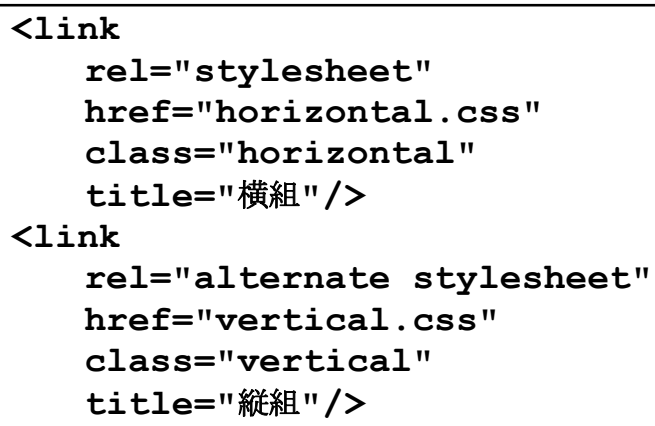

図 6 Alternative Style Tags

性 (属性值: ltr/rtl) を追加し, 綴じ方向を制御 する.また, CSS3 Writing Modes Module level3[22]の writing-mode プロパティを用い, 綴じ方向を自動的に制御する.

\section{Recommendation B1}

EPUB は元々米国で開発されたフォーマット であるため，版面内に左から右へ文字を配置 し，上から下へ行を配置するいわゆるラテン語 圈の横書き書字方向を持つ言語が念頭に置 かれている. そのため, 例えばアラビア文字や ヘブライ文字に見られる右横書き(右から左へ, 上から下に文字配置) や東アジア語圈で見ら れる縦書き(上から下へ, 右から左に文字配 置) は仕様上非対応である.

そのため, 多国語化対応として縦書き・横書 きそれぞれの書字方向をデフォルトの指定も 含め指定可能にする必要がある. また, 通常 縦書きの書籍であっても図表のキャプションは 横書きで記述されるため, デフオルト指定とは 別に部分的に書字方向を指定可能にする必 要がある.

そこで, 提案では OPS に対して CSS3 Writing Modes Module level3 を適用する. モ ジュールは direction と block-flow から構成さ れ, ショートハンドで記述できる. 図 5 に縦書き 時の writing-mode プロパティのショートハンド およびその分解例を示す。

\section{Recommendation B2}

EGLS では書字方向のフォールバックに関 して, OPS の参照仕様として Alternate Style Tags[23]の提案を行っている.この仕様は W3C CSS エディタである Elika J. Etemad 氏に よる提案である. HTML4.0 で定義されている 外部スタイルシートを指定するための link 要素 を拡張した仕様で, microformats の利用が検 討されている. 図 6 に Alternate Style Tags の 使用例を示す.

\section{Recommendation C}

以下で示す 4 種類の特に日本語特有の組 版処理を実現する手法が提案されている.

和欧文混植 


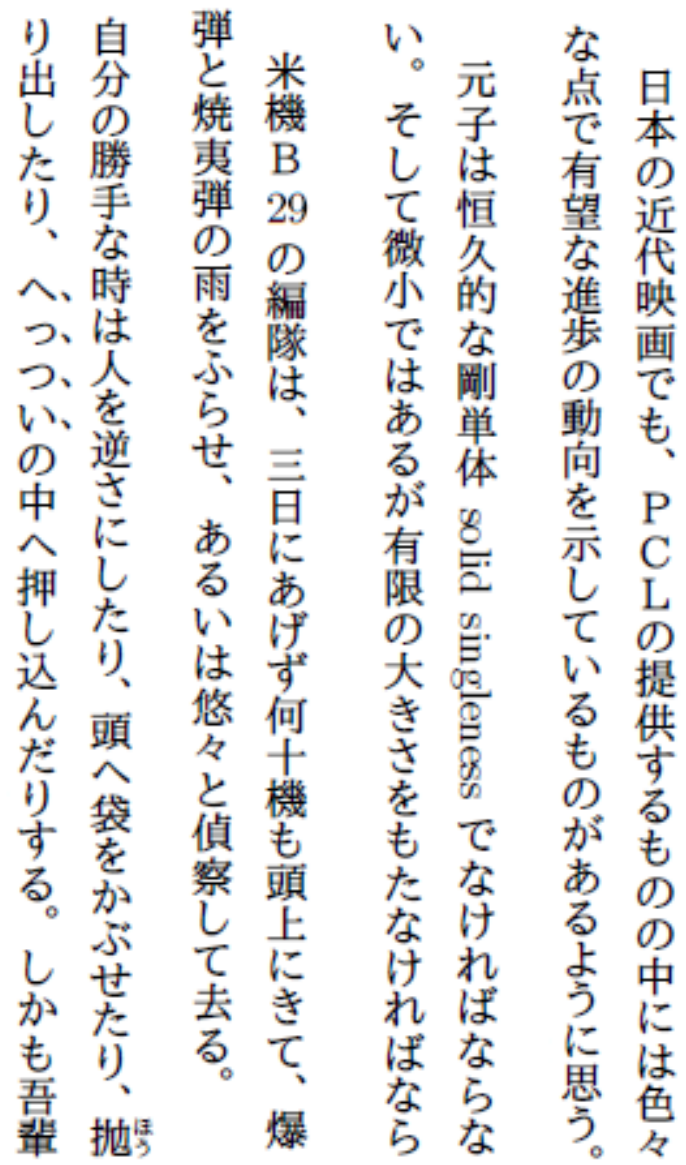

図 7 日本語特有の文字組版

日本語文字組版処理の一つに和文中にラ テン文字やギリシャ文字等の欧字・欧文が混 植する和欧文混植処理がある. 以下に和欧文 混植の例を示す。

1) 和文中に A や B といった欧字 1 字を記号と

\section{して使用する}

2) printing のように欧字を単語として使用する 和欧文混植を縦書きで実現するためには，そ れぞれ以下のような処理が必要となる.

1) 和文文字と同じ向きで 1 字 1 字配置する

2) 欧文文字を時計回りに 90 度回転させて配 置する

縦中横

縦中横処理とは, 縦書きの行中で, 縦書き の字の向きのまま横書きになるように文字列を 中央に配置する処理を指す。
行頭/行末禁則

•行頭禁則

行頭に配置されてはならない文字種がある。 そのような文字が行頭にきた場合，当該文字 を前の行に送り，前行の文字間を調整する (詰め処理)か, 前行の文字間を調節し, 行末 の文字を1文字追い出すことで当該文字が行 頭にくるのを防ぐ(延ばし処理).

•行末禁則

行頭禁則同様, 行末に配置されてはならな い文字種に対し，詰め・延ばし処理を適用す る.

圈点

圈点は, 漢字や仮名等の文字列に付け, そ の文字列を強調する役割を果たす。

図 7 に上記 4 点の文字組版例を示す. それ ぞれ，右から和欧文混植の欧字 1 字配置 (PCL) と行頭禁則詰め処理 $($ あるように思 う。), 和欧文混植の時計回りに 90 度回転 (solid singleness), 縦中横 (B29), 圈点 (へつ つい)となる.

EGLS ではこれら文字組版処理に対して， CSS3 Text Level3 の利用を提案している.こ のモジュールでは, テキストに対して改行文字 処理, 文字間の調整処理, 空白文字処理, 文 字装飾等を施すことが可能である.

\section{Recommendation D1 4}

ルビとは文字付近に読み方・意味等を示す 小さな文字を配置することを指す.ルビは配置 方法に応じて以下の 5 種類に分類することが できる.

1)モノルビ

ルビ配置対象文字(親文字) 1 文字に対して 1 文字のルビを配置する処理方法をモノルビと いう。

2)熟語ルビ

複数の漢字で構成される熟語に対してルビ 


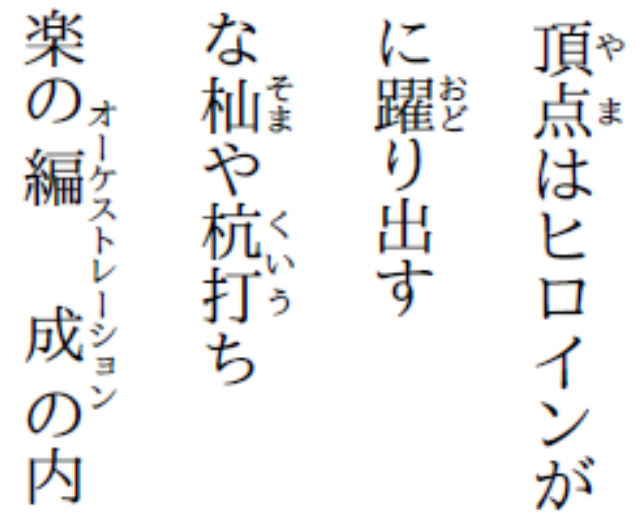

図 8 様々なルビ文字

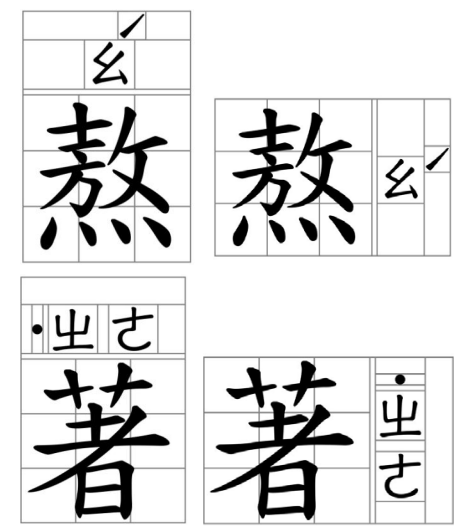

図 9 Bopomofoルビ

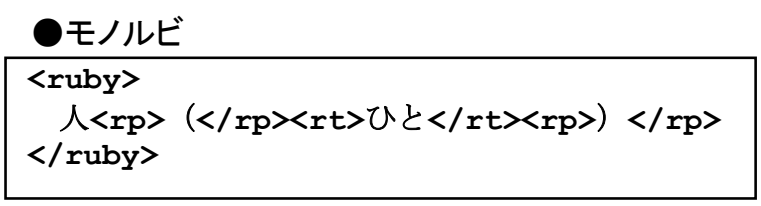

熟語ルビ
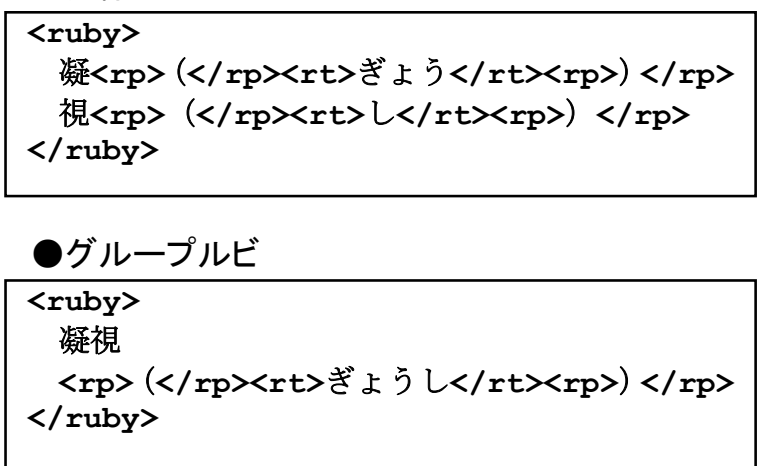

図 10 HTML5 Ruby の例
を配置する処理方法を熟語ルビという. 熟語 ルビはモノルビ同様に 1 文字ずつ配置する方 法と, 熟語単位で配置する方法がある.

3)グループルビ

親文字列に対して意味を表すルビを配置 する方法をグループルビという.

4)両側ルビ

親文字に対して, 左右 (あるいは上下)にル ビを配置する方法を両側ルビという。

5)Bopomofo ルビ

中国語の発音を記述する方法の一つに Bopomofoがある[24]. Bopomofo は横書きの場 合, 親文字の上側か右側, 縦書きの場合は右 側に配置する. また, ルビ文字には発音の強 弱を示すアクセント記号が付く.

EGLS の提案では, モノルビ・グループル ビ・Bopomofo ルビに関して, EPUB3.0 が HTML5 ベースでOPSを構成するならば, ruby 要素, rt 要素, 更には rb 要素も許容して利用 する.

また, 熟語ルビ・両側ルビについては, 利用 頻度, HTML5 Ruby[25]の実装検討により, 次 回改訂一見送りとしている.

ルビ文字は親文字の中心点に合わせて配 置する場合や，親文字の先頭に合わせて配 置する場合等，様々な位置に配置される. CSS3 Ruby Module[26]はルビ位置を指定する ための仕様である. しかしながら,このモジュ ールは仕様が固まっておらず, 実際の利用は 困難であるため, ルビ位置の指定についても 今回はスコープ外としている. なお, Bopomofo ルビに関してはアクセント記号を所定の位置 に配置する必要があるため, CSS3 Ruby Annotation Module[27]で位置指定ができるよ う, IDPF の Prefix バージョンを導入する. 図 8 に右からモノルビ (頂点, 踊り, 杣), 熟語ルビ (杭打ち), グループルビ (編成)の例を, 図 9 
に Bopomofo ルビの例を示す.また, 図 10 に 各ルビを HTML5 Rubyで実装した場合の例を 示す.

\section{Recommendation $\mathrm{E}$}

Unicode Normalization Form C (NFC) [28] は EPUB3.0 の仕様から削除することが提案さ れた。

\section{Recommendation $\mathrm{F}$}

Unicode における Private Use Characters (PUC) [29]の利用を推奨しないことが提案さ れた. PUC を用いる必要がある場合, PUC に 対してフォント埋込を行うことも併せて提案さ れた。

\section{Recommendation G}

メタデータの読みについて, OPF で指定す るメタデータに対して明確に xml:lang 属性を 指定することが提案された。

\section{Recommendation $\mathrm{H}$}

言語継承について, OPF 内にデフォルトの dc:language を指定することで，内包される OPS 全てがデフォルトに従うようにすることが 提案された.

\section{Recommendation I}

フォント埋込について, CSS Font Module Level3[30]を参照する. もしくは CSS2.0 のフォ ント仕様を参照することが提案された。

\section{Recommendation $\mathrm{J}$}

段方向について，段組および段方向を表 現するために, CSS Multi-column Layout Module[31]を参照することが提案された.

上記 Recommendation A から J は 2010 年 10 月 18 日〜20 日に米国サンフランシスコで 開催された実装案の検討対面会議において 全て承認された。

なお, 表 5 で示した当初要求項目のうち, No.18/19 のぶら下がり(Hanging Punctuation), No.16/17 の分割禁止文字 ( Unbreakable
Character Sequence), No.20/21 の分離禁止 文字(Non-Separating Characters), No.23 の 熟語ルビ (Jukugo Ruby), No.28 の両側ルビ (Multiple Ruby Text), No.33 のインライン画 像 (In-line Graphics)については, EGLS 内部 の検討段階において利用頻度の低さ, 実装で 用いる CSS3 モジュールの成熟度の低さを理 由に優先度を下げ，検討ワーキンググループ への提案を見送っている.

\section{6 むすび}

本稿では, 近年注目を集める電子書籍フォ 一マット EPUB において検討されている仕様 改訂の内容を概観した.

特に多国語化対応についてはIDPFの検討 ワーキンググループ内に設置された EGLS サ ブグループの活動を中心に, 東アジア語圏の 言語や文字組版がどのように仕様に反映され ているのか, いくつかの事例を交えて示した.

5 章で述べたように, 今回の改訂では綴じ 方向, 書字方向, 和欧文混植, 縦中横, 行頭 行末禁則, ルビ処理, Unicode 利用に関する 提案等, 多岐に渡る多国語化対応の改訂提 案がなされている. また, これらの提案は現在 の改訂ステータスにおいてほぼ仕様に反映さ れる予定となっている.

近年急速に立ち上がりつつある電子出版 市場において，読者に対して書籍への自由な アクセスと高い可読性を持つコンテンツの提 供が急務である.

EPUB は Web 標準技術をベースとするため， Web を基盤とする配信プラットフォームとの親 和性は高い.また，今回中心的に説明した多 国語化対応も国内外の専門家達を中心に強 力に推し進められており, 高い日本語表現能 力を持つコンテンツの普及が期待される. 


\section{付録 1}

\section{関連仕様}

- OPS 関連

(1) The XML 1.1 Extensible Markup

Language specification

http://www.w3.org/TR/xml11/

(2) Namespaces in XML 1.0 (Second

Edition)

http://www.w3.org/TR/xml-names11/)

(3) Document Object Model (Core) Level 1

http://www.w3.org/TR/REC-DOM-Level-1/l

evel-one-core.html

(4) XML Pointer Framework

http://www.w3.org/TR/2003/REC-xptr-fram ework-20030325/

(5) XHTML1.1 - Module-based XHTML -

Second Edition specification

http://www.w3.org/TR/xhtml11/

(6) Specifications for the Digital Talking

Book (DTB)

http://www.niso.org/standards/resources/Z

39-86-2005.html

(7) Scalable Vector Graphics (SVG) 1.1

Specification

http://www.w3.org/TR/SVG11/

(8) Cascading Style Sheets, level 2 specification

http://www.w3.org/TR/REC-CSS2

(9) The Unicode Standard, Version 4.0

(10) Particular MIME media types

http://www.ietf.org/rfc/rfc4288.txt

http://www.iana.org/assignments/media-ty pes/index.html

(11) Associating Style Sheets with XML

Documents

http://www.w3.org/TR/xml-stylesheet
(12) Web Content Accessibility Guidelines 1.0

http://www.w3.org/TR/WCAG10/

(13) RFC 2119: Key words for use in RFCs to Indicate Requirement Levels.

http://www.ietf.org/rfc/rfc2119.txt

(14) The OPF specification

http://www.idpf.org/opf/opf2.0/download/

(15) Namespace-based Validation

Dispatching Language (NVDL)

http://standards.iso.org/ittf/PubliclyAvaila bleStandards/c038615_ISO_IEC_19757-4_ 2006(E).zip

- OPF 関連

(1) The XML 1.1 Extensible Markup

Language specification

http://www.w3.org/TR/xml11/

(2) Namespaces in XML 1.0 (Second

Edition)

http://www.w3.org/TR/xml-names11/)

(3) The OPS Specification

http://www.idpf.org/ops/ops2.0/download/

(4) XHTML1.1 - Module-based XHTML -

Second Edition specification

http://www.w3.org/TR/xhtml11/

(5) Specifications for the Digital Talking

Book (DTB)

http://www.niso.org/standards/resources/Z

39-86-2005.html

(6) Dublin Core Metadata Element Set,

Version 1.1 specification

http://dublincore.org/documents/2004/12/20 /dces/

the MARC relator code list

http://www.loc.gov/marc/relators/

(7) The Unicode Standard, Version 4.0 
(8) Particular MIME media types http://www.ietf.org/rfc/rfc4288.txt

http://www.iana.org/assignments/media-ty pes/index.html

(9) Web Content Accessibility Guidelines 1.0

http://www.w3.org/TR/WCAG10/

(10) RFC 2119: Key words for use in RFCs to Indicate Requirement Levels.

http://www.ietf.org/rfc/rfc2119.txt

\section{- OCF 関連}

(1) The XML 1.1 Extensible Markup

Language specification

http://www.w3.org/TR/xml11/

(2) The OEBPS 1.2 Open eBook

Publication Structure specification

http://www.idpf.org/oebps/oebps1.2/index.h tm

(3) The XML 1.1 namespace specification http://www.w3.org/TR/xml-names11/

(4) The Unicode Standard, Version 4.0
(5) Particular MIME media types http://www.ietf.org/rfc/rfc4288.txt http://www.iana.org/assignments/media-ty pes/index.html

(6) Open Document Format for Office Applications (Open Document) v1.0 http://www.oasis-open.org/committees/dow nload.php/12572/OpenDocument-v1.0-os.p $\mathrm{df}$

(7) ZIP format http://www.pkware.com/business_and_dev elopers/developer/appnote

(8) XML-Signature Syntax and Processing http://www.w3.org/TR/2002/REC-xmldsig-c ore-20020212

(9) XML Encryption Syntax and Processing http://www.w3.org/TR/2002/REC-xmlenc-c ore- 20021210

(10) Web Content Accessibility Guidelines 1.0

http://www.w3.org/TR/WCAG10/ 


\section{参考文献}

［1］田代真人：「電子書籍元年 iPad\&キンド ルで本と出版業界は激変するか?」，インプ レスジャパン, 240p., 2010.

［2］北原義弘; 岩崎圭介; 田中秀明：「電子出 版とXMDF」，シャープ技報，Vol.84， pp. 13-17, 2002.

[3] $\mathrm{BBeB}$

http://en.wikipedia.org/wiki/BBeB (2010年10 月29日参照）

[4]EPUB Specification

http://www.idpf.org/specs.htm（2010年10月 29 日参照）

[5]（財）日本規格協会 情報技術標準化研究 センター：「ユビキタス社会を推進する情報 基盤の標準化調査研究 成果報告書」, 321p., 2007.

[6] IDPF (International Digital

Publishing Forum)

http://www.idpf.org/（2010年10月29日参照）

[7] OCF1. 0(Open Container Format1.0) http://www.idpf.org/ocf/ocf1.0/index.htm (2010年10月 29 日参照)

[8] OPS2. 0.1(0pen Publication

Structure2.0.1)

http://www.idpf.org/doc_library/epub/OPS_2.

0.1_draft.htm（2010年10月29日参照）

[9] OPF2. 0. 1 (Open Packaging Format2. 0.1) http://www.idpf.org/doc_library/epub/OPF_2. 0.1_draft.htm（2010年10月29日参照）

[10] Dublin Core Metadata Initiative http://dublincore.org/（2010年10月29日参照） [11] DAISY Consortium http://www.daisy.org/（2010年10月29日参照） [12] ANSI/NIS0 Z39. 86-2005 Specification for the Digital Talking Book
http://www.daisy.org/z3986/2005/Z3986-2005 .html（2010年10月 29日参照）

[13] The XHTML 1.1 Document Type http://www.w3.org/TR/xhtml11/doctype.html (2010年10月 29日参照)

[14] CSS2 Specification

http://www.w3.org/TR/2008/REC-CSS2-2008 0411/fonts.html\#font-descriptions（2010年10 月 29 日参照)

[15] EPUB2. 1 Working Group Charter Approved 5/24/2010

http://www.idpf.org/idpf_groups/IDPF-EPU B-WG-Charter-5-24-2010_Approved.html （2010年10月 29 日参照）

[16] epub-revision Timeline http://code.google.com/p/epub-revision/wiki/ Timeline（2010年10月 29日参照)

[17] epub-revision EGLS Sub-group http://code.google.com/p/epub-revision/wiki/ EGLS（2010年10月 29日参照）

[18] epub-revision SapporoEGLSMeeting http://code.google.com/p/epub-revision/wiki/ SapporoEGLSMeeting（2010年10月29日参 照)

[19] epub-revision EGLSTaipeiMeeting http://code.google.com/p/epub-revision/wiki/ EGLSTaipeiMeeting（2010年10月29日参照） [20] EGLS requirement ranking https://spreadsheets.google.com/ccc?key=0A gfCGamghC9odHVkZ1JqRmtaRnhYUjdVR $25 U U V h O Z H c \& h l=j a \#$ gid $=0 （ 2010$ 年 10 月 29 日参照)

[21] Enhanced Global Language Support (EGLS) in EPUB Subgroup Recommendation

http://www.asahi-net.or.jp/ eb2m-mrt/epub/ rec2WGRev.html（2010年10月29日参照） 
[22] CSS Writing Modes Modules Level 3

http://dev.w3.org/csswg/css3-writing-modes/ (2010年10月 29 日参照)

[23] Alternate Style Tags

http://fantasai.inkedblade.net/style/specs/alt ss-tags/（2010年10月29日参照）

[24] Bopomofo

http://en.wikipedia.org/wiki/Bopomofo (2010 年10月 29 日参照)

[25] HTML5 The ruby element

http://dev.w3.org/html5/spec/text-level-sema

ntics.html\#the-ruby-element（2010年10月 29 日参照)

[26] CSS3 Ruby Module

http://www.w3.org/TR/css3-ruby/（2010年10

月 29 日参照)
[27] CSS3 Ruby Annotation Module http://dev.w3.org/csswg/css3-ruby/ (2010年10 月 29 日参照)

[28] UAX\#15 Unicode Normalization Forms http://unicode.org/reports/tr15/（2010年10月 29 日参照)

[29] Private Use Characters

http://en.wikipedia.org/wiki/Private_Use_A rea\#Private_use_characters（2010 年 10 月 29 日参照）

[30] CSS3 Fonts Module Level 3

http://dev.w3.org/csswg/css3-fonts/（2010 年 10 月 29 日参照)

[31] CSS Multi-column Layout Module http://www.w3.org/TR/css3-multicol/ (2010 年 10 月 29 日参照) 